\title{
Analysis of Groundwater Quality of Aligarh City, (India): Using Water Quality Index.
}

\author{
KHWAJA M. ANWAR and VANITA AGGARWAL \\ Department of Civil Engineering, Maharishi Markandeshwar University, Mullana, Ambala, India. \\ http://dx.doi.org/10.12944/CWE.9.3.36
}

(Received: August 16, 2014; Accepted: September 21, 2014)

\begin{abstract}
Water is essential for all living organisms for their existence and metabolic process. Unethical human intervention in natural system and over exploitation of groundwater resources induces degradation of its quality. In many instances groundwater is used directly for drinking as well as for other purposes, hence the evaluation of groundwater quality is extremely important. The present study is aimed to analyze the underground water quality at Aligarh. In this study 80 water samples were collected from 40 places and analyzed for 14 water quality parameters for pre-monsoon and post-monsoon seasons (2012). The water quality index of these samples ranges from 18.92 to 74.67 pre-monsoon and 16.82 to 70.34 during post-monsoon. The study reveals that $50 \%$ of the area under study falls in moderately polluted category. The ground water of Aligarh city needs some treatment before consumption and it also needs to be protected from contamination.
\end{abstract}

Key words: Groundwater quality, water quality index (WQI), Assigned unit weight, Physico-chemical parameters.

\section{INTRODUCTION}

Water is called matrix of life because it is an essential part of all living systems and is the medium from which life evolved and in which life exists ${ }^{1}$. It is well known that human health and survival depends upon use of uncontaminated and clean water for drinking and other purposes. Groundwater is a good source of fresh water available on the earth, due to its relatively low susceptibility to pollution in comparison to surface water and its large storage capacity. It is estimated that approximately one third of the world's population uses groundwater for drinking purposes and today more than half of the world's population depends upon groundwater for survival ${ }^{2}$. The anthropogenic isturbances induce degradation of groundwater quality. Groundwater quality degradation occurs when its quality parameters are changed beyond their natural variations by the introduction or removal of certain substances ${ }^{3}$.
Groundwater is the only source of water supply in the study area. A study conducted by Atiq on the prevalence of diseases in Aligarh city concluded that $55 \%$ of the total households sampled suffer from diarrhea and dysentery, $43 \%$ jaundice ${ }^{4}$. Down to earth reports that more than $80 \%$ of the groundwater in Aligarh is susceptible to contamination with $50 \%$ of the city's groundwater resources at high risk, $24 \%$ moderately vulnerable and only $19 \%$ somewhat safe ${ }^{5}$. Keeping this in view, the main objective of the present study is to analyze various physico-chemical parameters of ground water quality and development of water quality index (WQI). The evaluation of groundwater quality and WQI could be useful for groundwater users and policy makers to take remedial measures.

\section{Study area}

The Aligarh is an ancient city in the north Indian state of Uttar Pradesh is situated in the middle 
of doab-the land between The Ganga and Yamuna rivers, at a distance of $130 \mathrm{Km}$ Southeast of Delhi on the Delhi- Howrah rail route and the Grand Trunk road. Aligarh lies between latitude $27^{\circ} 54^{\prime}$ and $28^{\circ}$ north and Longitude is $78^{\circ}$ and $78^{\circ} 5^{\prime}$ east. The Aligarh city is spread over an area of about $36.7 \mathrm{~km}^{2}$. The area lies between the Karwan River in the west and the Senger River in the east and is a part of central Ganga basin. It is the administrative headquarter of Aligarh division. Aligarh is mostly known as a university city where the famous Aligarh Muslim University is located. The Aligarh city is an important centre of lock smithy and brassware manufacturing. There are a total of 5506 industrial units in Aligarh city, of these; there are 3500 small scale industries, 2000 medium scale 6 large industries. Environmental quality of the area deteriorates mainly as a result of the increasing industrial activities. In order to find out the current status of the pollution in the area, due to the increasing trend in the industrial activities, it is very much essential to identify the various sources of pollution. All segments of environment are being polluted by various ways. However, the study of water pollution is selected as it is not an ordinary liquid but is the elixir of life.

Aligarh has a monsoon influenced humid subtropical climate. July is the wettest month. The normal annual rainfall is $760 \mathrm{~mm}$. Maximum temperature shoots upto $47^{\circ} \mathrm{C}$ and minimum temperature may fall around $2{ }^{\circ} \mathrm{C}$. The average relative humidity in the morning is $62.25 \%$ and in the evening it is $44.2 \%$. Hydrogeologically there is a three to four tier aquifer system. Aquifers seem to merge with each other, thus, developing a single body's aquifer. This makes the aquifer vulnerable to contamination $^{6}$

\section{MATERIAL AND METHODS}

Forty water samples were collected each during pre-monsoon (May) and post-monsoon (November) seasons during the year 2012. These samples were collected as per the standard methods prescribed for sampling. Plastic bottles of 1.5 liter capacity with stopper were used for collecting samples. Each bottle was washed with $2 \%$ Nitric acid and Location map of Aligarh citythen rinsed three times with distilled water. Samples analyzed for $\mathrm{pH}$, Turbidity, Total Dissolved Solids (TDS), Hardness,
Chloride, Sulfate, Total Alkalinity, Fluoride, Iron, Calcium, Magnesium, Nitrate, Zinc, Copper, in the laboratory of U.P. Jal Nigam, Aligarh. All the tests were conducted in accordance with the techniques described by American Public Health Association (APHA 1998) ${ }^{7}$.

$\mathrm{pH}$ was measured by digital $\mathrm{pH}$ meter micro processor based model no: LPV 2550 t. 97, 2002 make: HACH USA. Electrical conductivity (EC) and total dissolved solids (TDS) were measured with digital EC-TDS analyzer model No: CM 183, make Elico, India. Turbidity was measured by using Nephalo-meter model No: 2100 Q-01 make: Hach USA. Iron, Nitrate, Sulfate, Fluorides, Calcium, Magnesium, Copper, Zinc, ion concentrations were determined by spectrophotometer, using UV-Vis laboratory spectrophotometer (Model No: DR 5000) make Hach, USA. All the general chemicals used in the study were of analytical reagent grade (Merck/BDH). Standard solutions of metal ions were procured from Merck, Germany, Fisher Scientific, Mumbai and Rankem from RFCL limited, New Delhi. Various statistical analyses of the experimental data were performed using Microsoft Excel 2007.

\section{Water quality index (WQI) Estimation}

The water quality index (WQI) is regarded as one of the most effective ways to communicate water quality ${ }^{8}$.The water quality index (WQI) is a mathematical instrument used to transform large quantities of water quality data into a single number which represents the water quality level [9]. The objective of the index is to turn complex water quality data into information that is understandable and useable by the public. In a number of national wide studies, water quality of different natural resources has been assessed on the basis of calculated water quality indices ${ }^{10}$.

WQI of groundwater were calculated using the methods proposed by Horton ${ }^{11}$ and modified by Tiwari and Mishra ${ }^{12}$. According to the role of various parameters on the basis of importance and incidence on the overall quality of groundwater, the rating scales were fixed in terms of ideal values of different physic-chemical parameters. Even if, they are present, they might not be the ruling factor. Hence, they were assigned zero values. For calculating WQI, the following four equations were used: 
1. Quality rating, $Q_{n}=100[(V n-V i) /(V s-V i$ )]

Where

$V n$ : Actual amount of $n^{\text {th }}$ parameter

$\mathrm{Vi}$ : The ideal value of this parameter,

$\mathrm{Vi}=0$ Except for $\mathrm{pH}, \mathrm{Vi}=7.0$ for $\mathrm{pH}$

Vs : Recommended standard of corresponding parameter.

2. Assigned Unit Weight $\left(\mathrm{W}_{\mathrm{n}}\right)$ for various parameters is inversely proportional to the recommended standard $\left(S_{n}\right)$ for the corresponding parameter.

$\mathrm{W}_{\mathrm{n}}=\mathrm{K} / \mathrm{S}_{\mathrm{n}}$

Where K: Constant

$\Sigma \mathrm{W}_{\mathrm{n}}=1$

$\mathrm{n}=14$

3. Sub indices, $(\mathrm{SI})_{\mathrm{n}}=\left(\mathrm{Q}_{\mathrm{n}}\right)^{\mathrm{Wn}}$

4. The overall WQI was calculated by taking geometric mean of these sub indices. $\mathrm{n}=14$

WQI $=$ Anti $\log _{10}\left[\Sigma W_{n} \log _{10} Q_{n}\right]$ $\mathrm{n}=1$

On the basis of a number of water pollution studies following assumptions for suitability of water for human consumption are made on the basis of WQI values are rated as follows ${ }^{13}$ :
0-25 = Excellent,

26-50: Good,

51-75: Bad (Moderate Contaminated),

76-100: Very bad (Excessively Contaminated) and above 100 : Unfit (Severely Contaminated).

\section{RESULTS AND DISCUSSION}

\section{Groundwater quality variation}

The results obtained were evaluated in accordance with the standards prescribed by Bureau of Indian Standards under Indian standard drinking water specification IS: 10500:2012 of ${ }^{14}$.

$\mathrm{pH}$

The $\mathrm{pH}$ of a solution is the negative logarithm of Hydrogen ion concentration in moles per liter. pH values ranged from 7.52 to 8.79 during pre-monsoon period and 7.42 to 8.74 during post monsoon period. $56.25 \%$ of samples were above the standard limit ( 6.5 to 8.5$)$ prescribed by BIS.

\section{Total Dissolved Solids (TDS)}

TDS is used as an indication of aesthetic characteristics of drinking water and as an aggregate indicator of the presence of a broad array of chemical contaminants. The TDS values in the present study vary from 229 to $980 \mathrm{mg} / \mathrm{l}$ during pre-monsoon and 221 to $973 \mathrm{mg} / \mathrm{l}$ in post-monsoon period. $42.5 \%$ of samples were above the standard limit $(500 \mathrm{mg} / \mathrm{l})$ prescribed by BIS. Water with high TDS are of

Table.1: Parameter wise W.H.O. standards and their assigned unit weights

\begin{tabular}{lcccc}
\hline SI. No. & Parameters & $\begin{array}{c}\text { Standard values (Vs) } \\
\text { as per BIS:10500:2012 }\end{array}$ & $\begin{array}{c}\text { Ideal } \\
\text { value (Vi) }\end{array}$ & $\begin{array}{c}\text { Assigned unit } \\
\text { weight (Wn) }\end{array}$ \\
\hline 1 & $\mathrm{pH}$ & $6.5-8.5$ & 7 & 0.021294 \\
2 & TDS in $\mathrm{mg} / \mathrm{l}$ & 500.0 & 0 & 0.000319 \\
3 & Turbidity in NTU & 1.0 & 0 & 0.159702 \\
4 & Iron in $\mathrm{mg} / \mathrm{l}$ & 0.3 & 0 & 0.532340 \\
5 & Nitrate in $\mathrm{mg} / \mathrm{l}$ & 45.0 & 0 & 0.003194 \\
6 & Sulfate in $\mathrm{mg} / \mathrm{l}$ & 250.0 & 0 & 0.000639 \\
7 & Fluorides in $\mathrm{mg} / \mathrm{l}$ & 1.0 & 0 & 0.159702 \\
8 & Chloride in $\mathrm{mg} / \mathrm{l}$ & 250.0 & 0 & 0.000639 \\
9 & Alkalinity in $\mathrm{mg} / \mathrm{l}$ & 100.0 & 0 & 0.001597 \\
10 & Hardness in $\mathrm{mg} / \mathrm{l}$ & 200.0 & 0 & 0.000799 \\
11 & Calcium in $\mathrm{mg} / \mathrm{l}$ & 75.0 & 0 & 0.002129 \\
12 & Magnesium in $\mathrm{mg} / \mathrm{l}$ & 30.0 & 0 & 0.005323 \\
13 & Copper in $\mathrm{mg} / \mathrm{l}$ & 0.05 & 0 & 0.079851 \\
14 & Zinc in $\mathrm{mg} / \mathrm{l}$ & 5.0 & 0 & 0.031940 \\
\hline
\end{tabular}


inferior palatability and may induce an unfavorable physiological reaction in the transient consumers and gastrointestinal irritation. Naturally occurring total dissolved solids arise from the weathering and dissolution of rocks and soils.

Table. 2: The Analytical results showing quality of groundwater during Pre and Post-monsoon (2012) in the study area

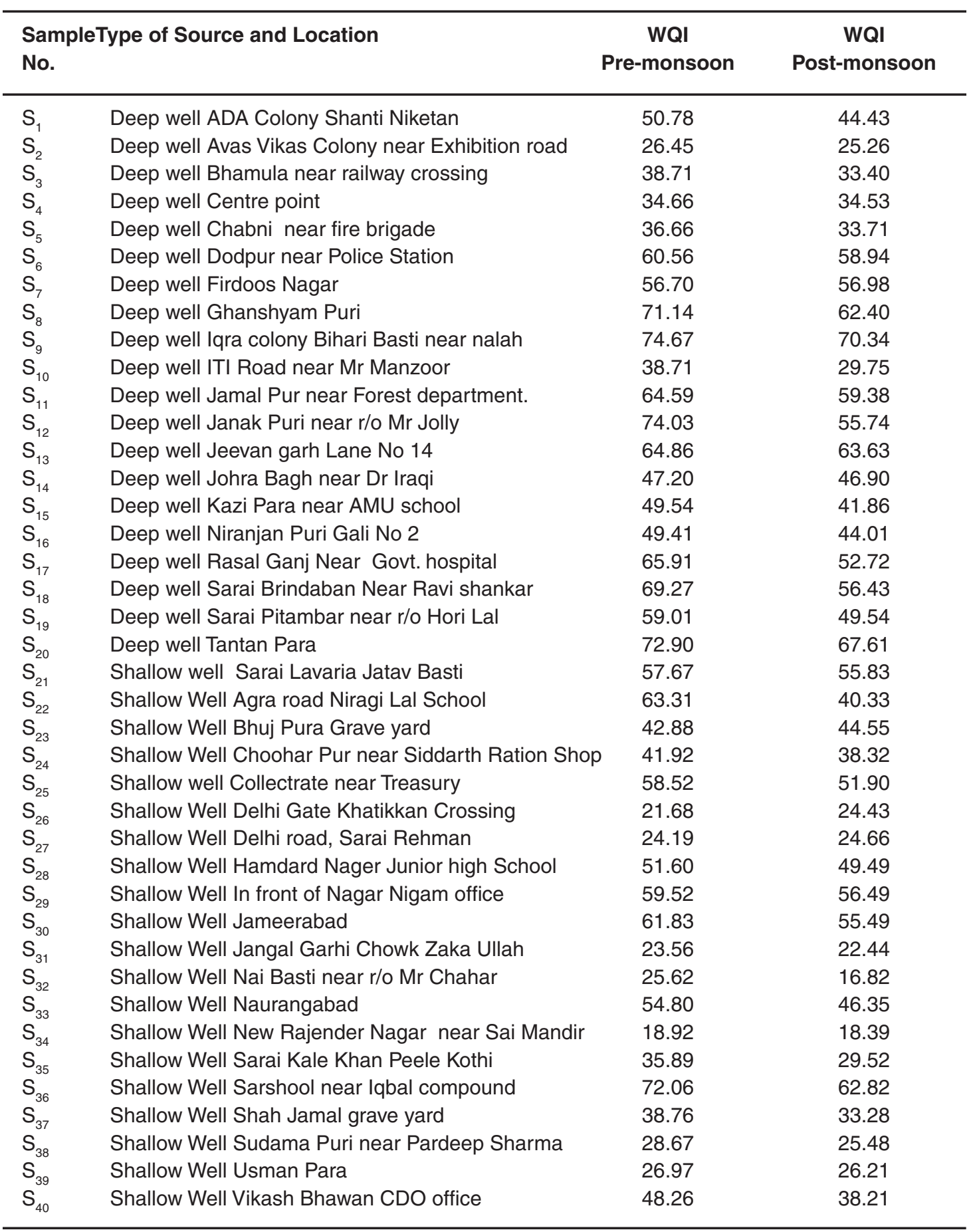




\section{Turbidity}

The turbidity for all the samples is below the BIS Standards limit 5.0 NTU. The highest value of turbidity is 2.4 NTU during pre-monsoon and 1.98 NTU during post-monsoon period. Turbidity in water causes degradation in clarity.

\section{Iron}

Iron concentrations in this study varied from 0.10 to $0.65 \mathrm{mg} / \mathrm{lin}$ pre-monsoon period and 0.09 to 0.60 during post-monsoon period. $62.5 \%$ of samples were found above the standard limit $(0.30 \mathrm{mg} / \mathrm{l})$ prescribed by BIS. Iron is a common metallic element found in the earth's crust Iron can affect the flavor and color of food and water. Iron is biologically an important element which is essential to all organisms and present in hemoglobin system.

\section{Nitrate}

The highest value of Nitrate is $26.58 \mathrm{mg} / \mathrm{l}$ during pre-monsoon and $25.12 \mathrm{mg} / \mathrm{l}$ during postmonsoon period. All the samples is below the BIS Standards limit $45.0 \mathrm{mg} / \mathrm{l}$. Nitrate-nitrogen $\left(\mathrm{NO}_{3}-\mathrm{N}\right)$ in groundwater may result from point sources such as sewage disposal systems and livestock facilities, non-point sources such as fertilized cropland.

\section{Sulfates}

Sulfate concentration in the area ranged from 11.6 to $384.0 \mathrm{mg} / \mathrm{l}$ during pre-monsoon and 12.3 to $381.5 \mathrm{mg} / \mathrm{l}$ in post-monsoon period. $30 \%$ of samples were found above the standard limit (200 $\mathrm{mg} / \mathrm{l})$ prescribed by BIS. Dehydration has been reported as a common side-effect following the ingestion of large amounts of Sodium sulfate ${ }^{15}$.

\section{Fluorides}

The fluoride values in the study area ranges from 0.02 to $0.80 \mathrm{mg} / \mathrm{l}$ in pre-monsoon and 0.01 to $0.72 \mathrm{mg} / \mathrm{l}$ during post monsoon period. The fluorides concentration in all the samples is below the BIS standards limit $1.0 \mathrm{mg} / \mathrm{l}$. Fluoride is beneficial for human beings as a trace element, this protects tooth decay and enhances bone development, but excessive exposure to fluoride in drinking-water, or in combination with exposure to fluoride from other sources, can give rise to a number of adverse effects $^{16}$.
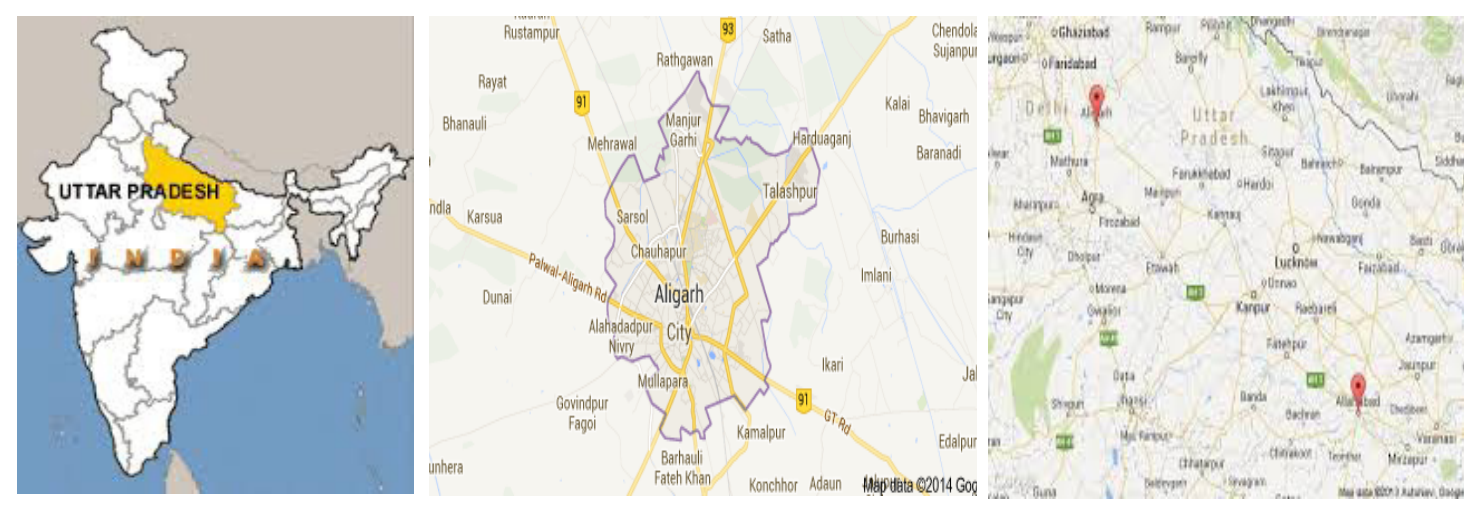

Location map of Aligarh city

Table. 3: Water quality classification based on WQI values

\begin{tabular}{llcc}
\hline \multirow{2}{*}{$\begin{array}{l}\text { WQI value } \\
\text { range }\end{array}$} & Water quality & \multicolumn{2}{c}{ Nos of sampling points } \\
\cline { 3 - 4 } & & Pre-monsoon & Post-monsoon \\
\hline $0-25$ & Excellent, Fit for human consumption & 4 & 5 \\
$26-50$ & Good & 16 & 20 \\
$51-75$ & Bad, Moderately Contaminated & 20 & 15 \\
$76-100$ & Very bad, Excessively contaminated & 0 & 0 \\
$>100$ & Severely contaminated Unfit for human consumption & 0 & 0 \\
\hline
\end{tabular}




\section{Chlorides}

In the present study, chlorides content of underground water varied from 25 to $464 \mathrm{mg} / \mathrm{l}$ in pre-monsoon and 27.0 to $436.0 \mathrm{mg} / \mathrm{l}$ during post monsoon period. $30 \%$ of samples were found above the standard limit $(250 \mathrm{mg} / \mathrm{l})$ prescribed by BIS. Chloride concentrations vary widely in natural water and it directly related to mineral content of the water. At concentration above $250 \mathrm{mg} / \mathrm{l}$, water acquires salty taste which is objectionable.

\section{Alkalinity}

The alkalinity varies from 219 to $528 \mathrm{mg} / \mathrm{l}$ in pre-monsoon and 212 to $476 \mathrm{mg} / \mathrm{l}$ during post monsoon period. $100 \%$ samples were found above the standard limit $(200 \mathrm{mg} / \mathrm{l})$ prescribed by BIS. Water with high alkalinity is said to be "hard." The most prevalent mineral compound causing alkalinity is calcium carbonate, which can come from rocks such as limestone or can be leached from dolomite and calcite in the soil. Large amount of alkalinity imparts a bitter taste to water.

\section{Total Hardness}

Total hardness is a measure of the capacity of water to the concentration of calcium and magnesium in water and is usually expressed as the equivalent of $\mathrm{CaCo}_{3}$ concentration. In the present study, the total hardness of the water samples ranges between 212 and $598 \mathrm{mg} / \mathrm{l}$ during pre-monsoon and 198 to 605 during post monsoon $98.8 \%$ of samples were found above the standard limit $(200 \mathrm{mg} / \mathrm{l})$ prescribed by BIS. Hard water is useful in the growth of children, if within the permissible limit.

\section{Calcium}

The Calcium concentrations are varied from 25 to $464 \mathrm{mg} / \mathrm{l}$ during pre-monsoon season where as in the post-monsoon season it ranges between 48 to $113 \mathrm{mg} / \mathrm{l} .43 .8 \%$ of samples were found above the standard limit $(75 \mathrm{mg} / \mathrm{l})$ prescribed by BIS.

\section{Magnesium}

The magnesium concentrations are varied from 38.88 to $115.88 \mathrm{mg} / \mathrm{l}$ during pre-monsoon season where as in the post-monsoon season it ranges between 36.45 to $119.6 \mathrm{mg} / \mathrm{l}$. 100\% samples were found above the standard limit $(30 \mathrm{mg} / \mathrm{l})$ prescribed by BIS.

\section{Copper}

The Copper concentrations are varied from 0.006 to $0.203 \mathrm{mg} / \mathrm{l}$ during pre-monsoon season where as in the post-monsoon season it ranges between 0.004 to $0.189 \mathrm{mg} / \mathrm{l} .33 .8 \%$ of samples were found above the standard limit $(0.05 \mathrm{mg} / \mathrm{l})$ prescribed by BIS.

\section{Zinc}

The zinc concentrations are varied from 0.012 to $1.813 \mathrm{mg} / \mathrm{l}$ during pre-monsoon season where as in the post-monsoon season it ranges between 0.011 to $1.794 \mathrm{mg} / \mathrm{l}$. It can be observed that all the samples having Zinc value below $5.0 \mathrm{mg} / \mathrm{l}$ fall within the limits for both the seasons.

\section{WQI Analysis}

The physico-chemical parameters with their BIS water quality standard values, corresponding weightage factor $\left(\mathrm{W}_{\mathrm{n}}\right)$ assigned with the help of equation no 2 and ideal values are presented in table 1.WQI calculations were made from equations number 3 and 4 . The WQI results for the premonsoon period and post-monsoon period (2012) are presented in table no 2 . Water quality index base classification of all the water samples is presented in table no 3.

The results revealed that the groundwater of 4 locations during pre-monsoon season and 5 locations during post-monsoon season of the study area was in excellent quality of water where WQI ranges from 0-25 best suitable for human consumption. The remaining areas of samples are ranging between good to moderately contaminated.

\section{CONCLUSION}

The present study of underground water samples reveals that about $50 \%$ of the area under study comes under moderately polluted category and there is marked variation in groundwater quality. The analytical results shows higher concentration of Alkalinity (100\%), magnesium (100\%), hardness (98.8), iron (62.5\%), $\mathrm{pH}$ (56.25), calcium (43.8\%) and TDS (42.5\%) which indicates signs of water quality deterioration as per BIS standards. 
The study emphasizes the urgent need for regular underground water quality monitoring to assess pollution activity from time to time for taking appropriate measures in time to mitigate the intensity of pollution activity. Augmenting the groundwater resources by recharging the ground water aquifers through rain water harvesting and thus reducing the high concentration of the chemical parameters is a very important measure. Public awareness program should be initiated to create a sense of awareness to save water around their habitants.

\section{ACKNOWLEDGEMENTS}

The author is thankful to Dr Navneet Kumar, Department of Applied science, TMU, Moradabad for helping in bringing out the paper in the present form. The author is also thankful to Er Mohammad Owais, Executive Engineer U.P. Jal Nigam Aligarh for providing necessary facilities.

\section{REFERENCES}

1. F, Franks, "Water: A Matrix of Life", 2nd Edition, RSC Paperback, UK, pp 225(2000).

2. Mohrir A. Ramteke D.S.,Moghe C.A., Wate S.R. and Sarin R."Surface and Groundwater Quality Assessment in Binaregion", IJEP, 9; 22(2009).

3. Ramesh, R., Subramanian, V. and Ramanathan, A.L. "Point and Non-point sources of Groundwater Pollution: Case Studies along the East Coast of India," Proceedings of the International Workshop on Ecohydrology, Capital Publishing Company, New Delhi, India,pp107 (2001).

4. Atique Rahman, "Assessing Income-Wise Household Environmental Conditions and Disease Profile in Urban Areas: Study of an Indian City," Geo Journal, 65(3) 211-227 (2006).

5. Down to Earth, http://www.downtoearth.org. in/(2008).

6. Khan T. A., "Trace Elements in the Drinking Water and their possible Health Effect in Aligarh City, India". Journal of Water Resource and Protection, 3; 522-530(2011).

7. APHA, "Standard methods for the examination of water and wastewater", sixteenth edition. American Public Health Association, Washington D.C., USA (1998).

8. Mahapatra, M. K. and Mishra R. K. "Groundwater pollution in subarampur and Nuapada district of Orissa," Poll. Res., 24(4) ; 863-865 (2005).

9. Saeedi M., Abessi O., Sharifi F., Meraji
H,'Development of groundwater quality index," Journal of Environtal Monitoring Assessment, 163; 327-335,(2010).

10. Sinha, D. K. and Saxena, R., "Statistical Assessment of Underground drinking water contamination and effect of monsoon at Hasanpur, J. P. Nagar (Uttar Pradesh, India)," Journal of Environment science and Engg., 48(3); 157-164 (2006).

11. Horton,R.K.," An index number system for rating water quality", Journal of Water Poll. Control Federation, 37(3); 300-306,(1965).

12. Tiwari,T.N. and Mishra, M.A.,"A preliminary assignment of water quality index of major Indian rivers", Indian J. Env. Protection. 5(4); 276-279(1985).

13. Mishra P. C., Patel R. K.,"Quality of drinking water in Rourkela, outside the steel township" Journal of Env. And Pollution, 8(2); 165169(2001).

14. IS: 10500: 2012 Indian Standard, Drinking Water-Specification, Second Revision, Bureau of Indian Standards, Manak Bhawan, 9. Bahadur Shah Zafar Marg New Delhi, (2012).

15. www.who.int/water sanitation health/dwq/ chemicals/sulfate.

16. Kundu,N.,Panigrahi,m., Tripathy,S., Munshi,S., Powell,M.A. and Hart, B.R., Geochemical appraisal of fluoride contamination of groundwater in the Nayabagh district, Orrisa", Environ. Geol., 41; 451-460(2001). 